UNTAG Law Review (ULREV)

Volume 1, Issue 2, Nov 2017, PP 10-18

ISSN 2549-4910 (online) \& ISSN 2579-5279 (print)

http://jurnal.untagsmg.ac.id/indeks.php/ulrev/indeks

www.fakhukum.untagsmg.ac.id

\title{
CRIME OF ABORTION STUDY IN INDONESIA
}

\author{
Frans Simangunsong
}

Student of Doctoral Program of the Law Faculty of Sultan Agung Islamic University, and Lecturer of Law Faculty University of Surakarta, contact at email : franspatikawa@gmail.com

\begin{abstract}
Abortion is a social phenomenon that is increasingly alarming. The concern is not without reason, because so far the behavior of abortion many negative effects both for themselves perpetrators and the community at large. In terms of positive law in Indonesia, there is still debate and opposition from the pros and cons about the perception or understanding of the laws that exist to this day. Neither of Health Law, the Law on medical practice, The Criminal Code (Penal Code), Law on the elimination of domestic violence (domestic violence), and the Law on Human Rights (HAM). Normative legal research(normative law research) using the product in the form of case studies of normative legal behavior. Factors that led to the crime of abortion is rampant in Indonesia, partly because the sex education curriculum(sex education)in schools has been less effective in tackling promiscuity among teenagers. Therefore, the role of parents is very important in instilling moral values, ethics, law and religion. Sexual promiscuity among teenagers Indonesia today is alarming. Efforts to tackle the crime of abortion in the study of law in Indonesia. As for things - things that must be done by governments, institutions, communities and families in tackling illegal abortions are: Government: Providing spectacle qualified educate and prohibit the spectacle that does not make sense and did not educate as patron wearing tight uniform, Soon follow-up of cases - cases of illegal abortion and impose penalties sufficient to deter; Society: Society as a social institution should be more sensitive control and participate on everything that exists within its territory, reinforcing the social control in society
\end{abstract}

Keywords: Assessment, Crime, Abortion

\section{INTRODUCTION}

The problem of evil is one of the social problems that are always interesting and demanding attention from time to time. Moreover, according to the general assumptions as well as some observations and research of various parties, there is an increasing trend of certain forms and types of crimes, both in quality and quantity. ${ }^{1}$ Life is a gift given by God almighty One who must be respected by everyone. Life is given to every human being is a human rights can only be revoked by the Giver of life. Talking about the abortion of course we are talking about human life through abortion close relation to the woman and the fetus in the womb of women.

1 Moh. Kemal Darmawan, 1994 "Crime PreventionStrategy",Citra Bakti, Bandung, , p.1 
Abortion (abortion) is always a debate, both in official and unofficial forums related to the fields of medicine, law and other disciplines. Abortion is a social phenomenon that is increasingly alarming. The concern is not without reason, because so far the behavior of abortion many negative effects both for themselves perpetrators and the community at large.

In terms of positive law in Indonesia, there is still debate and opposition from the pros and cons about the perception or understanding of the laws that exist to this day. Neither of Health Law, the Law on medical practice, the Criminal Code (Penal Code), Law on the elimination of domestic violence (domestic violence), and the Law on Human Rights (HAM).

Before the revision of health legislation is still much debate about abortions performed by rape victims. That's because there is no clause that clearly addresses on abortion for victims of rape. During this time many of the views that interprets likened abortion to rape victims with medical indications that can be done due to the mother's psychological disturbances can also threaten the life of the mother. However the other hand there is also a view that abortion for victims of rape is a criminal abortion because they do not endanger the life of the mother and the Health Act No. 23 of 1992 does not explicitly contained in the article. With the release of the revision of the health legislation regarding the legalization of abortion for victims of rape have been included clearly in Article 75 paragraph 2 of Law 36 of 2009 on the health.

In the Criminal Code (Penal Code) while the provisions relating to the issue of abortion and its causes can be found in Chapter XIX of the Criminal Code Section 229.346 s / d 349 which contains a clear prohibition of abortion while in the health provisions of Law No. 36 of 2009 on Health regulate abortion provisions of Article 76,77,78. There are differences between the Criminal Code by Act No. 36 Year 2009 on Health in regulating the abortion issue. Penal Code expressly prohibiting abortion for any reason, while the Health Act to allow abortion on emergency medical indications as well as rape. But the abortion provisions in Law No. 36 of 2009 still there are limits that should not be violated, such as the condition of pregnancy up to 6 weeks after the first day of the last menstrual period. Also based on the Health Act 36 of 2009, the medical act (abortion), in an attempt to save the pregnant woman or her fetus can be done by health workers who have the expertise and authority to do so and performed in accordance with professional responsibility and team considerations expert. It shows that the abortion be legal or justifiable and legally protected. However, this situation is contrary to the Law of Human Rights Article 53 concerning the right to life of children from starting the fetus until birth. In this case can be seen still much debate about whether or not abortion is legal according to the law and public spectacles

Abortion case in 2016, the demolition of a septic tank in the toilet abortion clinic in Menteng, Central Jakarta. Findings, there are about 22 pieces of bone in the baby clinic in Jalan Cimandiri, and 8 pieces in Clinic Road Cisadane. Operation longstanding abortion and gestational age varies. "There is a measure of bone according to the theory of pregnancy has been 6 months and it is definitely baby's bones. Earlier, the Special Criminal Investigation Directorate Metro Jaya Regional Police discovered the drain hole of the fetus in the toilet clinic where abortions in Menteng, Central Jakarta." Initially during the inspection they do not admit, it turns out we found the hole in the two crime scenes (the crime scene). In the clinic Cisadane Road No. 19 is different from the drain hole fetus down the toilet. The clinic in Cimandiri street, the drain hole is located inside the toilet. Has been aborted fetuses dumped in sewage. Currently, police have arrested ten suspects from the two clinics. ${ }^{2}$

2 https://m.tempo.co/read/news/2016/03/04/064750916/kasus-aborsi-di-menteng-polisi-temukan-22pieces of bone 
Every year, one out of every four pregnancies ends in abortion, so estimates are based studies of the World Health Organization (WHO) and the Institute Guttmacher. Report loaded Lancet said as many as 56 million women have abortions each year, higher than expected previous. Para researchers justify the abortion rate decreased rich countries, but warned in poor areas the situation is still worse over the last 15 years.

Scientists say the number of abortions worldwide annual increase of 50 million per year between 1990 to 1994 to 56 million per year between 2010-2014. The increase in the number of abortions most commonly seen in developed countries - partly driven by population growth and by the desire to have a small family. Their calculations show that, at a time when the number of abortions per person is not much change in poor countries, even in rich countries dropped from number 25 to 14 men per 1,000 women of reproductive age. The researchers found a similar abortion rates in many countries - regardless of whether the act of termination of pregnancy is legal or not. They argue that laws against abortion do not limit the number of abortions and vice versa can cause people to seek illegal abortions that are not safe for them. ${ }^{3}$

An estimated 2.3 million unsafe abortions occur every year in Indonesia. "As many as 1 million of spontaneous miscarriage, 700 thousand due to unwanted pregnancies, and 600 thousand due to failure of family planning. 15 percent of abortions are performed by groups of teens less than 20 years. The average pregnancy is an abortion or aborted pregnancies without contraception. ${ }^{4}$

Community perspective abortion is one of the social aberrations that occur in the community. Abortion is identical on pregnant are not expected, delinquency and promiscuity. Though abortion is also done by a mother who was unable to continue her pregnancy (endanger the mother) and the result of rape. In the medical world, abortion is broadly divided into two (2) types of sorts, namely spontaneous abortion and abortion provocatus. SAB commonly known as miscarriage, abortion while provocatus abortions done on purpose. Abortion provocatus divided into two (2) that abortion legal provocatus (on safety considerations mother) and provocatus abortion illegal (criminal provocatus abortion) that abortion with the intent to kill the fetus on ${ }^{5}$ purpose. The provocatus against abortion measures are Law governing law.

\section{Problems}

1. What factors are causing the crime of abortion?

2. How to tackling the crime of abortion in the study of the positive law in Indonesia?

\section{METHODS}

Research normative law(lawnormativeresearch)using case studies of normative legal behavior in the form of products, such as reviewing legislation. Principal study is conceived as a norm of law or rules in force in the community and made reference to the behavior of every person. So the normative legal research focuses on the inventory of positive law, principles and legal doctrine, legal discovery in the case in concreto, systematic law, the level of synchronization, comparative law and legal history. ${ }^{6}$ The approach method in this paper is the approach of legislation(statueaproach). ${ }^{7}$ A normative study would have to use the approach of

3 http://life.viva.co.id/news/read/139051-2-3-juta

4 http://www.bbc.com/indonesia/majalah/2016/05/160512_majalah_kesehatan_aborsi-aborsi-yearhappen-in-Indonesia

5 Ratna Dewi Pudiastuti, Community Midwifery (Yogyakarta: Medical Book, 2011), p 48

6 Abdulkadir Muhammad. 2004. Hukum dan Penelitian Hukum.Cet. 1. Bandung: PT. Aditya Bakti image. P. 52

7 Peter Mahmud Marzuki. 2008.Penelitian Hukum.Cet 2. Jakarta: Kencana. It 29 
legislation, because that will be examined are various laws that are the focus at the same time the central theme of a study.

\section{DISCUSSION}

\section{Factors that cause the crime of abortion}

Abortion in Indonesia translated english dictionary with abortion. ${ }^{8}$ In Blaks's Law Dictionary, the word abortion which translates to an abortion in the Indonesian language means: "The spontaneous or induced articially expulsion of an embryo or featus. As used in the context of illegal Refers to induced abortion. ${ }^{9}$ Miscarriage with the release of the embryo or fetus is not merely because it occurs naturally, but also intentional or due to interference (provocation) human. ${ }^{10}$.In general terms criminalist abortion provokatus dalah a premature birth before the baby was in time to live on her own outside the womb. In general, the fetus out was already lifeless. ${ }^{11}$ While legally abortion provokatus criminalist is any termination of pregnancy before the conceptus is born, regardless of age of the baby in the womb and the fetus is born dead or alive. ${ }^{12}$ The Code of Penal (Penal Code criminalize abortion without exceptions so that women seeking abortions do so quietly and choose to use the services of personnel who are not professionals.

Abortion is happening today is more based on the sociological reasons than the reasons medical. the reasons for this sociological prohibited and may include criminal acts, namely abortion provokatus criminalist punishable offense. When translated, there are several reasons that are used by women to abort both legal and illegal due to not wanting to continue the pregnancy until delivery. reason -The reason: ${ }^{13}$

a. Health reasons are vital if there are indications that occur during pregnancy, if continued to threaten and endanger the lives of the mother and non-vital medical indications that occurs during pregnancy and estimates based doctor, if continued will worsen the physical and psychological health of the mother. In addition, based on fetal health reasons, namely to avoid the likelihood of birth defects and mental physical, although this reason can not be accepted as the basis of medical considerations.

b. The social reasons; not all women pregnancy is a pregnancy is desired, it means there are unwanted pregnancies by reason many children, pregnant outside of marriage as a result of promiscuity, pregnant due to rape or incest, infidelity and so on. Women who have unwanted pregnancies trying to fall pregnant either through the intermediary of a medical (doctors) nor the artisan clandestine abortions despite the high risk.

c. Reasons of economy, increasing employment opportunities, especially for women are also considered factors that will influence the increase in abortions, economic development towards industrial economy through manufacturing economy will rapidly

8 Echols and Hassan Shaddily DictionaryEnglish Indonesia,(Jakarta: Gramedia, 1992), p. 2.

9 Henry Campbell Black's, Black's LawDictionary, Sixth Edition, St. Paul Min West Publising Co., p. 1.

10 Translation abortion according to Black's Law Dictionary, is taken from Suryono Ekototama, etal., , 2001 Abortion for Rape Perspective Prookatus iktimologi,Criminology and Criminal Law, (Yogyakarta: Uniersitas Atmajaya), p. 31.

11 Sri Setyowati, 1976 criminalist Abortion Issue in Indonesia and Their Relation to the Family Planning Viewed from the Book of Law Criminal Law, (Jakarta: TP,), p. 99 and 22.

12 Handoko Tjondroputranto, 1996 "Teaching Abortion provokatus", (Jakarta: May 6, 1872) in Lilik Iswatin, Abortion Provokatus Criminalists (Comparative Study Between Islamic Criminal Law In Criminal Law Positive), (Yogyakarta: Thesis Faculty of Sharia, TP,), p. 53.

13 Dewi Novita, 1997 Abortion in Health Officers (Yogyakarta: first-aid-UGM), hlm.16-20. See also in Yayah Chisbiyah, et al, unwantedpregnancies, (Yogyakarta: first-aid-UGM, 1997), p. 47. 
increase the number of young women absorbed as workers, also followed higher education. Consequently marriage delay occurred, but biologically they had moved during the sexually active. Sex outside marriage will increase, mainly triggered by means of entertainment, media film that offers a vulgar sex life. Abortion is also considered as the right choice for their work contract to be pregnant during the first two years of work and if not abortion risk is fired from a job. Unpreparedness reason the economy is also often a consideration for married women who did not want her pregnancy to have an abortion, such as the failure of family planning, low income is insufficient to cover the cost of living.

d. The reason an emergency (force), pregnancy due to rape. Pregnancies that occur as a result of coercion (rape) sex (intercourse) man to woman.

\section{Efforts to tackle the crime of abortion in the study of the positive law in Indonesia}

Regulations on abortion in Indonesia there are few regulations governing the implementation of the abortion, the Penal Code, Law Number 36 Year 2009 on health and Government Regulation No. 61 Year 2014 on reproductive health. However, the appearance of the article about the permissibility of abortion for victims of rape in Law Number 36 Year 2009 on health and Government Regulation No. 61 of 2014 raises a big question considering it was contrary to the Civil Code, Article 2 of Law No. 23 of 2002 article 1 on the protection of children, Act No. 39 of 1999 article 52 (2) and article 53 (1) of the Human Rights and the Criminal Code, which is still valid. The effect of the Legalization of Abortion on Women the Victim of Rape based on the Health Act Number 36 of 2009, Articles 75, 76, and 77.

The right to live is the first one of basic human rights. The respecting of the right to live is the basic condition for the human being to function as the way it should. However, there is an essential factor of items, namely, the personal consent, people may not be Sacrificed with any reasons without the consent from Reviews those who is given the task to guard his / her life. With the noble reasons it is justifiable when someone wants to sacrifice his / her life, but it is not justifiable when the human is Sacrificed for Certain reason. Therefore, the respecting of the basic right to live Becomes the main requirement for a society to be called as prestigious and having high culture. Viewed from the Basic Human Right perspective, a woman has the right to get abortion service, Because it is the very fundamental right of reproductive health. The Act Number 36 of 2009 contains the provision of Article 72 about the guarantee for anyone carrying out reproduction. But, in this case, abortion is an Inevitable need for the woman who does not want her pregnancy Because of certain reason. Reproductive health is the fully physical, mental, and social well-being that not only frees from disease, defect, Relating to the reproductive system and function. The basic principles of sexual and reproductive rights include:

a. Bodily integrity, the right to own body, not only freed from physical torture and violence, but also can enjoy the potential body for health, giving birth, and safe sexual enjoyment.

b. Personhood, Refers to the woman's right to be needed as the actor and decision maker in sexual and reproductive problems and as the subject in the related policy.

Equality, the equality between man and woman and between the women Themselves, not only in terminating the gender, race, and class discrimination but Also guaranteeing the presence of social justice and conditions favorable for the women, for example: the access to the reproductive right, ${ }^{14} a$. Diversity, the appreciation of the value of orders, need, and priority the

14 Toptimal iton Slamet Kurnia, Hak Atas Derajat Kesehatan Optimal Sebagai HAM di Indonesia, Alumni, Bandung 
woman has and defined by the woman herself consistent with her existence as an individual and a member of certain society.

Abortion is justifiable if it contains legitimate defense ${ }^{15}$ People have the right to defend his / her life against invasion of other's obviously threatening his / her life. The most important objective is to defend (to maintain) his / her life. The objective of such action is to save the mother's life and fetal death is only the effect of such the action that is Objectively forced to happen. However, on the basis of abortion justification as Mentioned in the Health Act, people then justifies the abortion act with the argument that woman has the right to her own body to Determine by herself what is good and not good for her life. However, the effect of abortion Legalization based on the health act for the woman the victim of rape has weaknesses as well, Including:

a. The one aborting her pregnancy in the objective of escaping from her responsibility as a mother but using rape victim reason as the justifying Because reason for her act only her personal viewing interests without taking into account the right of the fetus in her uterine and it frequently Occurs with the adolescents caught in the free-sex leading to unexpected pregnancy because of a no-readiness to be a mother.

b. Abortion can be said as something essential raping a woman having instinct as the life giver has. Everyone Believes that human being is created by God and derives his / her life from God. And it is everyone's obligation to respect other's life Including the fetus in her body. Human's life should be maintained and protected Because It has high values.

c. A pregnant woman with unexpected because of raping sometimes can think deeply because of the psychological trauma she experiences. Nevertheless, the presence of unexpected fetus is not only the fetus's desire and pregnancy abortions Becomes the alternative choice to forget the events she experiences. But, such the act is not a prudent decision, Because The better way is to treat the psychological trauma of the woman the victim of rape experiences and continue her life forward with the fetus in her fibroids so that she no longer escapes from difficulty and problem she faces because of raping by sacrificing others 'or the fetus' life. The fetus should be maintained Because there is no reason harmful to the mother's and fetus's life safety event because of raping the victim UNLESS there is a reason of diseases dangerous to the life of the mother or infant to be born in the future.

Abortion provocatus criminalist under Article 346 through 349 of the Criminal Code. The sound of the chapters are as follows :

a. Article 346: a woman who intentionally abort or shut down abortion or tell others to it, threatened with imprisonment for a period of four years.

b. Article 347 of the Criminal Code

(1) Whoever intentionally abort or lethal womb of a woman without her consent, punishable by a maximum imprisonment of twelve years.

(2) If the act that resulted in the woman, subject to a maximum imprisonment of fifteen years.

c. 348 of the Criminal Code

(1) Whoever intentionally abort or lethal womb of a woman with her consent, punishable by a maximum imprisonment of five years and four months.

15 CB Kusmaryanto, 2002, Kontroversi aborsi, Gramedia widiasarana Indonesia, Jakarta, p. 85 
(2) If the act results in the death of the woman, subject to a maximum imprisonment of seven years.

d. Article 349 of the Criminal Code: If a doctor, midwife or clerk Abat help commit the crime of the article 346, or performing or helping commit one of the crimes described in Articles 347 and 348, then the punishment specified in the article can be augmented by a third and deprived to run the occupation in which the crime was committed. ${ }^{16}$

PAF Lamintang gives explanation to those articles are as follows: ${ }^{17}$

a. Abortion of content can only be punished if the child is in the womb during an abortion attempt is made to be in life. The law does not recognize a legal presumption can be concluded that children who are in it are alive or have the possibility to stay alive. (HR 1 November 1897. W.7038)

b. To abortion could be punished, required that children in the womb during the abortion attempt is made to be alive. Not necessary that the child be dead because of the abortion business. The fact that the child was born unharmed, does not remove that the crime was completed. The law does not distinguish between less or more smooth growth of children who live in the womb, but the separation from the mother's body that was not in time as acts that can be punished. (HR 1898 W. 12 April 7113)

c. Required that a child in the womb is alive and perpetrator had intent to abort children who are alive that. It is considered that there is a deliberate, if during the birth of the child was alive and the offender encompassed by the notion that this is so. (HR 1907 July $29 \mathrm{~W}$. $8580)$.

d. The tools of evidence mentioned by the judge in the verdict should be drawn to a conclusion, that the woman is pregnant and bear children who live and that the accused had the intention to deliberately cause a fall or death of the child. (HR December 20, 1943, 1994 No. 232).

Articles about abortion provokatus mentioned above, threatening anyone who intentionally causes abortion (abortion), both for the perpetrator as well as for helper abortion doctors, midwives, medicine, herbalists and other medical experts with the penalty doubled, with no exceptions for any reason. At this time, it was not relevant rules to be applied as opposed to political Indonesian laws protect and prosper all the Indonesian people.

Stemming illegal abortion behavior not easy to reverse both hands. According to our group of illegal abortions would not exist if no one wants to have an abortion. Therefore to prevent such things should start from the most basic thing that moral education. Advances in technology now if not matched by moral education would be a big bomb that could blow up the next generation. The few things that must be done by governments, institutions, communities and families in tackling the illegal abortion is:

a. Government

- Provides educational quality spectacle and spectacle prohibit unreasonable and did not educate as soap operas that tight uniform.

- Immediate follow-up of cases - cases of illegal abortion and impose penalties sufficient to deter.

b. Community

- Society as a social institution should be more sensitive control and participate on everything that exists within its territory.

- Reinforces the social control in society. No doubt that makes teens free to do whatever is due to the weakening of social control in the family and society. Suppose there is a 
pair of actors "courtship" that allowed her parents are both-be a pair in the room. Although adultery does not occur there, but it can lead to actions that "more" to be done on other occasions, and other places. Likewise, the control of society it is important when we see young couples staying in the boarding room and even going on for days. This of course could further encourage deviant behavior in terms of performing the acts that should just be done by the couple officially.

c. Institution/School

- For second homes are expected to have activities - activities that strengthen faith and provide education about the dangers of promiscuity, abortion etc.

d. Family

- As the family had to create a harmonious atmosphere in the foster home because usually a pregnant woman is not desirable come from broken homes who never took care of children-her son

\section{CONCLUSION}

1. Factors that led to the crime of abortion is rampant in Indonesia, partly because the curriculum of sex education(sexeducation) in schools has been less effective in tackling promiscuity among teenagers. Therefore, the role of parents is very important in instilling moral values, ethics, law and religion. Sexual promiscuity among teenagers Indonesia today is alarming.

2. Efforts to tackle the crime of abortion in the study of law in Indonesia. As for things things that must be done by governments, institutions, communities and families in tackling the illegal abortion is: Government: Providing spectacle qualified educate and prohibit the spectacle that does not make sense and did not educate as patron wearing tight uniform, Soon follow-up of cases - cases of illegal abortion and impose penalties sufficient to deter; Society: Society as a social institution should be more sensitive control and participate on everything that is in the area, reinforcing the social control in society.

\section{RECOMMENDATION}

There should be an Increased awareness among the society of the danger of out of marriage relationship, free sex leading to the infant disposal crime occurrence. The improvement of socialization and comprehensive sex education, as well as the successfulness of family planning is expected can reduce the abortion rate. There should be cooperation between the societies to cope with any sexual acts outside of marriage propagating Widely among the society that initiates the cause of unexpected pregnancy.

\section{References}

Abdulkadir Muhammad. 2004. Hukum dan Penelitian Hukum.Cet. 1. Bandung: PT. Citra Aditya Bakti

C.B. Kusmaryanto, 2002, Kontroversi aborsi, Gramedia widiasarana Indonesia, Jakarta

Dewi Novita. 1997. Aborsi menurut Petugas Kesehatan, Yogyakarta: PPPK-UGM

Echols, dan Hassan Shaddily. 1992. Kamus Inggris In donesia, Jakarta: Gramedia

Henry Campbell Black's, Black's Law Dictionary, Sixth Edition, St. Paul Min West Publising

Moh. Kemal Darmawan. 1994. ’Strategi Pencegahan Kejahatan”, Citra Bakti, Bandung

Moeljatno. 1990.. Kitab Undang-undang Hukum Pidana Jakarta: Bina Aksara

P.A.F. Lamintang. 1990. Hukum Pidana Indonesia, Bandung: Sinar Baru

Peter Mahmud Marzuki. 2008.Penelitian Hukum.Cet 2. Jakarta: Kencana Ratna Pudiastuti Dewi. 2011. Kebidanan Komunitas . Yogyakarta : Medical Book 
Sri Setyowati. 1976. Masalah Abortus Kriminalis di Indonesia dan Hubungannya dengan Keluarga Berencana Ditinjau dari Kitab Undang-undang Hukum Pidana, TP, Jakarta

Suryono Ekototama, dkk.. 2001. Abortus Prookatus bagi Korban Perkosaan Perspektif iktimologi, Kriminologi dan Hukum Pidana, Yogyakarta: Uniersitas Admajaya

https://m.tempo.co/read/news/2016/03/04/064750916/ kasus-aborsi-di-menteng-polisi-temukan-22-potongantulang

http://www.bbc.com/indonesia/majalah/2016/05/160512_majalah_kesehatan_aborsi

http://life.viva.co.id/news/read/139051-2-3-juta-aborsi-setahun-terjadi-di-indonesia 